\title{
The evolution of nematode sex determination: $C$. elegans as a reference point for comparative biology*
}

\author{
Eric S. Haag ${ }^{\S}$, Department of Biology, University of Maryland, College
} Park, MD 20742 USA

\section{Table of Contents}

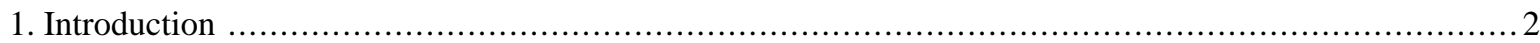

2. Genetic and environmental sex determination in nematodes .............................................. 2

3. Deep conservation and cooption in the evolution of nematode sex determination ............................ 3

4. Conservation of $C$. elegans pathway components: $C$. briggsae as the ruler .................................. 5

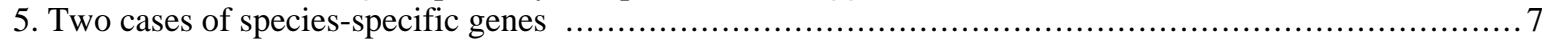

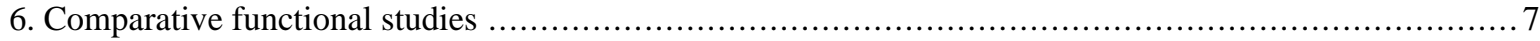

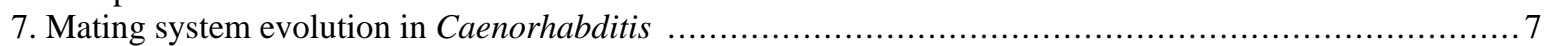

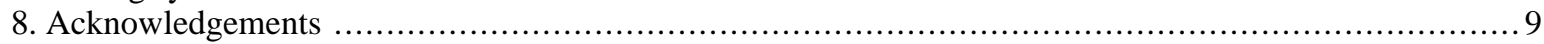

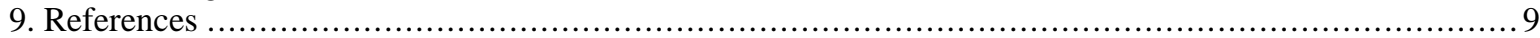

Abstract

Sex determination was a founding topic of $C$. elegans research. After three decades of research, a complex signal transduction pathway with multiple layers of regulation has been elucidated. This pathway links karyotype to phenotype by coordinating the development of sexually dimorphic tissues. In this article, this pathway is placed in two broader contexts. The first is that of nematodes and animals in general. The important role of $\boldsymbol{C}$. elegans studies in revealing the first universally conserved component of metazoan sex determination is discussed, as is the role of cooption of genes into the sex determination and dosage compensation pathways. The second context is that of a subset of more closely related species, with emphasis on other members of the genus Caenorhabditis. Studies reviewed here have determined the gene-level conservation of the known pathway and the relative rates of molecular evolution in conserved components, and made substantial progress in the manipulation of gene activity in non-elegans species. Special attention is paid to the origins of hermaphroditism, which evolved from gonochorism through germline-specific changes in sex determination. Recent studies suggest that the most rapidly evolving aspects of sex determination are germline functions related to evolutionary shifts in mating systems, while somatic sex determination is relatively conservative. From all of these studies, a picture emerges in which $C$. elegans utilizes an intriguing mixture of general and species-specific genes and regulatory mechanisms.

${ }^{*}$ Edited by Barbara J. Meyer. Last revised October 5, 2005. Published December 29, 2005. This chapter should be cited as: Haag, E. S. The evolution of nematode sex determination: . elegans as a reference point for comparative biology (December 29, 2005), WormBook, ed. The $C$. elegans Research Community, WormBook, doi/10.1895/wormbook.1.120.1, http://www.wormbook.org.

Copyright: $\odot 2005$ Eric S. Haag. This is an open-access article distributed under the terms of the Creative Commons Attribution License, which permits unrestricted use, distribution, and reproduction in any medium, provided the original author and source are credited.

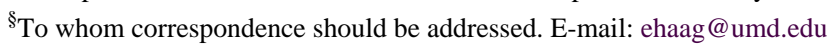




\section{Introduction}

Sex determination was one of the first aspects of $C$. elegans biology to be systematically characterized with genetic analysis (Hodgkin and Brenner, 1977), and the depth of this analysis has made it a major topic in developmental biology. It is both fair and interesting to ask how general the C. elegans model is likely to be, both for other nematodes as well as for animals in general. As nematodes employ many different reproductive strategies, often related to parasitic life histories (Anderson, 2000; Chitwood and Chitwood, 1950), one might expect similarly variable sex determination mechanisms. However, comparative studies of sex determination based on the $C$. elgans model have revealed both rapidly evolving and surprisingly well conserved features. This mixture of old and new (or slow and fast), along with its obvious relevance to evolution, ecology, and applied fields like agricultural and medical parasitology, has made the evolution of nematode sex determination an increasingly active research area.

\section{Genetic and environmental sex determination in nematodes}

In 1949, Nigon demonstrated that C. elegans used an XX/XO sex chromosome system, and the importance of the X:autosome ratio was clarified by Madl \& Herman (1979). The XX/XO system is widespread across the Nematoda, and may be ancestral (Bull, 1981; Bull, 1983). However, some groups have apparently abandoned genetic sex determination (GSD) in favor of environmental sex determination (ESD).

The best characterized example of nematode ESD is in the arthropod parasitic Mermithidae. In lightly infected hosts, exclusively female worms are born, while in heavily parasitized hosts only males are produced. At intermediate parasite densities mixed populations are produced (Christie, 1929; Harlos et al., 1980). Culture of mermithids in axenic liquid culture also produces only females, suggesting that the concentration of a limiting host factor may be an important cue for male development (Petersen, 1985). Whether the environmental factors that dictate sex impinge upon a signal transduction pathway resembling that mediating $C$ elegans sex determination is unknown, but just such a connection between nutrition and sex determination has recently been found in $C$. elegans itself (Prahlad et al., 2003). Among the small number of nematode fossil specimens that exist are mermithids emerging from their insect hosts, preserved in 40 million year old Baltic amber (Poinar, 2002). Their striking similarity to extant insect-parasitic species (Figure 1) suggests a minimum age for the origin of ESD in this group, although it is possible that ancient mermithids used GSD.

ESD also occurs in the vertebrate parasite Strongyloides, which like C. elegans is in the order Rhabditida. As with most parasitic nematodes, a dauer-like alternative L3 form serves as the infective stage. Once inside a host, infective worms all mature as females and reproduce by mitotic parthenogenesis (Anderson, 2000). Parthenogenetic progeny that remain in the host develop into apomictic females, like their mothers. However, when L1 larvae are passed from the host in feces, they can either develop into infective L3 female larvae (the homogonic path) or initiate a free-living male/female generation (the heterogonic phase) that is similar to Caenorhabditis. Heterogonic development produces males and females from genetically identical L1 larvae, indicating that sex is either stochastically or environmentally determined. This again resembles the sexual plasticity of C. elegans larvae recently described by Prahlad et al. (2003), in which a chemical cue induces specific loss of the paternal X chromosome in L1 larvae. It would be interesting to see if these phenomena share a common mechanism. 


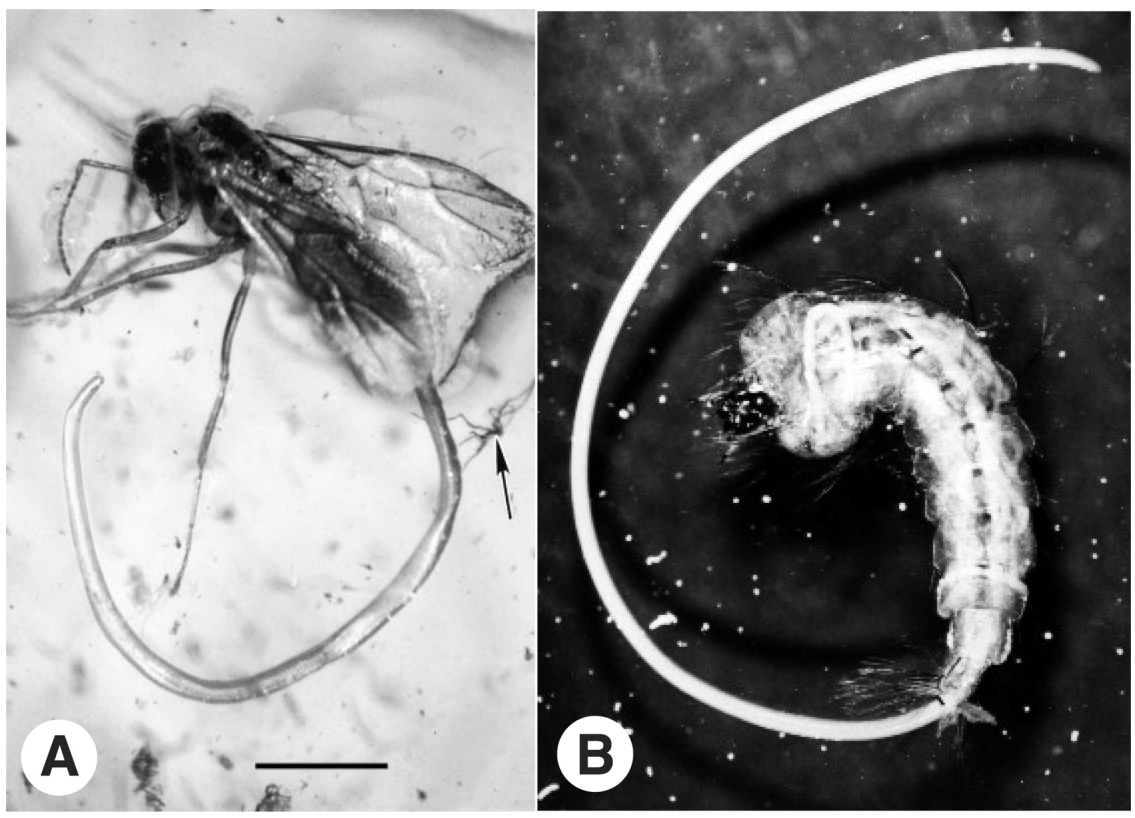

Figure 1. Ancient and extant mermithid nematodes emerging from their insect hosts. A. Juvenile worm of the genus Heydenius emerging from a winged male ant of the genus Prenolepis. The specimen is preserved in Baltic amber approximately 40 million years old. The scale bar represents 1.2 mm. Photograph reproduced from Poinar (2002) with permission from the author and Cambridge Univ. Press. B. Juvenile mermithid emerging from an extant mosquito larva. Photo used with permission of the Univ. of Nebraska, Lincoln Dept. of Entomology.

Commitment to heterogonic development in Strongyloides requires amphid neurons homologous to those that govern dauer formation in C. elegans (Ashton et al., 1998), indicating that the alternate reproductive modes are also environmentally controlled. Males are required for female fertility in the heterogonic phase, but apparently the male sperm serves only to activate embryogenesis. Diploidy is thought to be maintained by fusion of the post-meiotic oocyte pronucleus with an oogenic polar body (Anderson, 2000). The heterogonic phase is therefore pseudo-sexual, and presumably evolved from a truly sexual ancestor. Given that parasites often rely on genetic diversity for successful host invasion, this represents an unusual case that deserves further investigation.

\section{Deep conservation and cooption in the evolution of nematode sex determination}

Although C. elegans, Drosophila, and mammals (the three most-studied systems) all use GSD, the signal transduction pathways that convert the genetic difference between sex into dimorphic fates are not at all similar (Cline and Meyer, 1996). However, recently a conserved component has been discovered: the Doublesex/mab-3 (DM) family of transcriptional regulators (Figure 2, Raymond et al., 1998; Yi and Zarkower, 1999). Although mab-3 functions in specifying a limited number of male cell fates in C. elegans, the role of Dsx in Drosophila and of DM proteins in some vertebrates (Matsuda et al., 2002) indicate they can function more globally. The association of DM family member expression with sexual development in cnidarians (Miller et al., 2003) further suggests that this role evolved prior to the Cambrian, over 500 million years ago. It is reasonable to imagine that the first metazoans had sexual differentiation controlled in part by a DM progenitor, and that the diversity of extant sex determination mechanisms represents extreme divergence in different lineages. In this sense, then, sex determination itself is a homologous developmental process, even though the genes that control it are in most cases not themselves homologous.

How did the nematode system evolve? One interesting possibility is that much of it represents a highly modified form of the hedgehog $(h h)$ pathway. hh signaling controls many key patterning and cell fate decisions in metazoan development, but is conspicuously absent from $C$. elegans, as judged by the lack of bona fide $h h$ and smoothened homologs in the genome. However, the TRA-2 transmembrane receptor is topologically similar to patched, and the pathway culminates in the regulation of a Cubitus interruptus/Gli-like transcription factor, TRA-1. Perhaps in the distant past, as nematode development became more mosaic and increasingly dependent upon cell lineage, $h$ h signaling became dispensable for other aspects of development and was coopted into sex determination. Given the unusually high rates of sequence evolution exhibited by many sex determination genes, it is plausible that 
some "novel" proteins in the pathway may have at one time been recognizably similar to other $h h$-related homologs. The isolation of her-1 (Streit et al., 1999) and tra-1 (Pires-daSilva and Sommer, 2004) homologs from Brugia malayi (from the order Spirurida) and Pristionchus pacificus (Rhabditida, Neodiplogasteridae), respectively, suggests that this putative cooption happened early in the diversification of nematodes. In the case of Ppa-tra-1, multiple mutant alleles provide conclusive proof of a conserved female-promoting role.

\section{Drosophila $\quad$ C. elegans mammals}

$\begin{array}{llll}\text { signal } & \mathrm{X} \text { :A ratio } & \mathrm{X} \text { :A ratio } & \text { dominant } \mathrm{Y} \\ \begin{array}{l}\text { transduction } \\ \text { mechanism }\end{array} & \begin{array}{l}\text { cascade of } \\ \text { regulated } \\ \text { mRNA } \\ \text { splicing }\end{array} & \begin{array}{l}\text { membrane } \\ \text { receptor } \\ \text { pathway }\end{array} & \begin{array}{l}\text { SRY-mediated } \\ \text { regulation of } \\ \text { gonad development, } \\ \text { hormones }\end{array} \\ \begin{array}{l}\text { key male } \\ \text { target gene }\end{array} & D S X & \text { mab-3 } & \text { Dmrt1 }\end{array}$

Figure 2. Variation in model system sex determination. Though mammals, Drosophila, and C. elegans all use GSD, they interpret their sex chromosome content through distinct signal transduction pathways. However, all three eventually converge on a DM family member whose expression is associated with male development. Drosophila Dsx is unusual for DM genes in also having an important role in female development (through a female-specific splice variant).

There are two other likely cases of cooption of genes into Caenorhabditis sex determination, enabled through pleiotropic function of a single gene or the divergence of gene duplicates. First, the recent structural characterization of XOL-1 suggests that it is related to small molecule metabolic kinases (Luz et al., 2003). Whether XOL-1 actually acts as an enzyme is not yet clear, but the fact that it is the least conserved protein in the entire sex determination pathway suggests it may not. The other case is comprised of the dosage compensation complex genes. The products of mix-1, dpy-26, dpy-27, and $d p y-28$ are clearly related to the $13 \mathrm{~S}$ condensin complex that mediates chromatin condensation in vertebrates (Meyer, 2000). MIX-1 has been shown to play a direct role in both processes (Hagstrom et al., 2002), while $d p y-26, d p y-27$ and $d p y-28$ are replaced in cell division by products of the paralogs C29E4.2 (Hagstrom and Meyer, pers. comm.), smc-4 (Hagstrom et al., 2002), and hcp-6 (Chan et al., 2004), respectively.

In 1995, Wilkins proposed that the many layers of negative regulation found in nematode and Drosophila sex determination represent the accumulation of successive upstream repressors, the so-called "bottom up" hypothesis". The conservation of tra- 1 as a key female-promoting gene beyond the family Rhabditidae is consistent with this idea. However, if the signal transduction pathway used in Caenorhabditis sex determination is a diverged form of the hedgehog pathway, then one might predict that the entire "cassette" from her-1 to tra-1 came into the pathway at once, and thus will not be found in partial form in any species.

A more general test of the bottom-up idea will require examination of the more upstream components of the pathway, such as the $\mathrm{X}$ chromosome counting factors fox-1 and sex-1, in both close and distant relatives of $C$. elegans. Although the XX/XO system seems to be widespread across the Nematoda, this does not mean that $\mathrm{X}$ dosage is measured by homologous genes in all species. Although clear $C$. briggsae fox- 1 and sex- 1 homologs exist, their functions remain untested. As of early 2005 an effort to sequence the Pristionchus pacificus genome is underway, which should soon enable a search for these genes (or their equivalents) in a second nematode family. Recently, Hodgkin (2002) demonstrated that $C$. elegans can be manipulated genetically such that any of the core sex-determining genes (all autosomal), an extrachromosomal array, temperature, or even a suppressor tRNA locus can substitute for the X:A ratio as the primary determinant of sex. This impressive feat suggests that nature also has 
a large number of options at its disposal for optimization of reproductive strategy. It will be of great interest to see to what extent these options have, in fact, been used during nematode evolution.

\section{Conservation of $C$. elegans pathway components: $C$. briggsae as the ruler}

Homologs of $C$. elegans sex determination genes have been isolated from several Caenorhabditis species, including the undescribed male/female species CB5161 (Stothard et al., 2002), the male/female C. remanei (Chen et al., 2001; Haag and Kimble, 2000; Haag et al., 2002), and the non-rhabditids Pristionchus pacificus (Pires-daSilva and Sommer, 2004) and Brugia malayi (Streit et al., 1999). However, the nearly complete genome sequence assembly of $C$. briggsae (Stein et al., 2003) makes it uniquely suited to assess molecular conservation across the entire $C$. elegans pathway. The focus below is therefore on $C$. briggsae, but we shall return to the results of functional studies in the other species in a later section.

Nearly all C.elegans sex determination genes have clear C. briggsae orthologs, as judged by genomic synteny, reciprocal best BLAST scores, and in a few cases comprehensive phylogenies (Nayak et al., 2005; Stothard et al., 2002). Table 1 shows the amino acid conservation between these $C$. elegans and C. briggsae homologs. Most, but not all, of these genes show greater divergence than the genome-wide median conservation of $80 \%$ (Stein et al., 2003). Little correlation exists between where a gene acts in the pathway and its sequence conservation. One trend, however, seems to be higher conservation in proteins that are demonstrably or likely to be pleiotropic. For example, mag-1, mog-1, mog-4, and mog-5 all encode key pre-mRNA splicing factors (Belfiore et al., 2004; Li et al., 2000; Puoti and Kimble, 1999; Puoti and Kimble, 2000), and are extremely well conserved. Similarly, the RNA-binding GLD-1 has roles in both sex determination (Jan et al., 1999; Jones et al., 1996; Jones and Schedl, 1995a) and the mitosis-meiosis decision (Crittenden et al., 2002; Francis et al., 1995; Hansen et al., 2004; Kadyk and Kimble, 1998) in the $C$. elegans germ line.

Table 1. C. elegans-C. briggsae sex determination protein sequence conservation

\begin{tabular}{|c|c|c|c|}
\hline Gene & Role in sex determination pathway & Protein family or motifs & Amino acid identity \\
\hline $\operatorname{sex}-1$ & $\begin{array}{l}\text { X dosage counting element } \\
\text { (female-promoting) }\end{array}$ & $\begin{array}{l}\text { Zn-finger TF, nuclear hormone } \\
\text { receptor (Carmi et al., 1998) }\end{array}$ & $44 \% \mathrm{~B}$ \\
\hline fox -1 & $\begin{array}{l}\text { X dosage counting element } \\
\text { (female-promoting) }\end{array}$ & RRM (Hodgkin et al., 1994) & $87 \% \mathrm{~B}$ \\
\hline xol-1 & $\begin{array}{l}\text { integrator of } X \text { and autosomal dosage } \\
\text { (male-promoting) }\end{array}$ & $\begin{array}{l}\text { GHMP kinase-related (Luz et al., } \\
\text { 2003) }\end{array}$ & $\begin{array}{l}22 \% \text { (Luz et al., } \\
2003)\end{array}$ \\
\hline$s d c-1$ & $\begin{array}{l}\text { X dosage compensation complex } \\
\text { component, } \text { her- } 1 \text { transcriptional } \\
\text { repressor (female-promoting) }\end{array}$ & $\begin{array}{l}\text { Zn-finger TF (Nonet and Meyer, } \\
\text { 1991) }\end{array}$ & $39 \% \mathrm{~B}$ \\
\hline$s d c-2$ & $\begin{array}{l}\text { X dosage compensation complex } \\
\text { component, her- } 1 \text { transcriptional } \\
\text { repressor (female-promoting) }\end{array}$ & $\begin{array}{l}\text { novel, with coiled-coil (Dawes et } \\
\text { al., 1999) }\end{array}$ & $32 \% \mathrm{~B}$ \\
\hline $\begin{array}{l}s d c-3(\mathrm{aka} \\
d p y-29)\end{array}$ & $\begin{array}{l}\text { X dosage compensation complex } \\
\text { component, } \text { her }-1 \text { transcriptional } \\
\text { repressor (female-promoting) }\end{array}$ & $\begin{array}{l}\text { Zn-fingers, myosin-like ATPase } \\
\text { (Klein and Meyer, 1993) }\end{array}$ & $28 \% \mathrm{G}$ \\
\hline her-1 & $\begin{array}{l}\text { secreted signal coordinating gender } \\
\text { (male-promoting) }\end{array}$ & $\begin{array}{l}\text { novel, signal peptide (Hamaoka et } \\
\text { al., 2004; Perry et al., 1993) }\end{array}$ & $\begin{array}{l}\text { 57\% (Streit et al., } \\
1999)\end{array}$ \\
\hline tra-2 & $\begin{array}{l}\text { receptor for HER-1, repressor of fem } \\
\text { genes (female-promoting) }\end{array}$ & $\begin{array}{l}\text { 7-pass integral membrane protein } \\
\text { (Kuwabara and Kimble, 1995) }\end{array}$ & $\begin{array}{l}\text { 43\% (Kuwabara, } \\
1996)\end{array}$ \\
\hline tra-3 & $\begin{array}{l}\text { positive regulator of TRA-2 processing } \\
\text { (female promoting) }\end{array}$ & $\begin{array}{l}\text { calpain-related protease (Barnes and } \\
\text { Hodgkin, 1996) }\end{array}$ & $91 \% \mathrm{~B}$ \\
\hline laf-1 & $\begin{array}{l}\text { somatic repressor of } t r a-2 \text { translation } \\
\text { (male-promoting) }\end{array}$ & $\begin{array}{l}\text { noncoding RNA (Goodwin, pers. } \\
\text { comm.) }\end{array}$ & N/A \\
\hline gld-1 & $\begin{array}{l}\text { germline translational repressor of } t r a-2 \\
\text { (male-promoting) }\end{array}$ & $\begin{array}{l}\text { KH RNA-binding protein (Jones } \\
\text { and Schedl, 1995b) }\end{array}$ & $83 \% \mathrm{~B}$ \\
\hline
\end{tabular}


The evolution of nematode sex determination: $C$. elegans as a reference point for comparative biology

\begin{tabular}{|c|c|c|c|}
\hline Gene & Role in sex determination pathway & Protein family or motifs & Amino acid identity \\
\hline fog-2 & $\begin{array}{l}\text { germline cofactor of GLD-1, repressor of } \\
\text { tra-2 translation (male-promoting) }\end{array}$ & F-box (Clifford et al., 2000) & No clear ortholog \\
\hline mag-1 & $\begin{array}{l}\text { germline repressor of male-promoting } \\
\text { genes (female-promoting) }\end{array}$ & $\begin{array}{l}\text { magoH/mago nashi exon junction } \\
\text { complex (Li et al., 2000) }\end{array}$ & $97 \% \mathrm{G}$ \\
\hline fem-1 & $\begin{array}{l}\text { cytoplasmic responder to TRA-2 activity } \\
\text { (male-promoting) }\end{array}$ & ankyrin repeats (Spence et al., 1990) & $72 \% \mathrm{~B}$ \\
\hline fem-2 & $\begin{array}{l}\text { cytoplasmic responder to TRA-2 activity } \\
\text { (male-promoting) }\end{array}$ & $\begin{array}{l}\text { protein phosphatase 2C (Pilgrim et } \\
\text { al., 1995) }\end{array}$ & $\begin{array}{l}\text { 63\% (Hansen and } \\
\text { Pilgrim, 1998) }\end{array}$ \\
\hline fem-3 & $\begin{array}{l}\text { cytoplasmic responder to TRA-2 activity } \\
\text { (male-promoting) }\end{array}$ & novel & $\begin{array}{l}\text { 38\% (Haag et al., } \\
\text { 2002) }\end{array}$ \\
\hline$f b f-1,2$ & $\begin{array}{l}\text { germline translational repressors of } \mathrm{fem}-3 \\
\text { (female-promoting) }\end{array}$ & $\begin{array}{l}\text { Puf family RNA-binding protein } \\
\text { (Zhang et al., 1997) }\end{array}$ & No clear ortholog \\
\hline nos-3 & $\begin{array}{l}\text { germline cofactor of FBF-1/2, repressor } \\
\text { of fem-3 translation (female-promoting) }\end{array}$ & nanos-related RNA-binding domain & $51 \% \mathrm{~B}$ \\
\hline$m o g-1$ & $\begin{array}{l}\text { global repressor of } f e m-3 \text { translation } \\
\text { (female-promoting) }\end{array}$ & $\begin{array}{l}\text { DEAH RNA helicase (Puoti and } \\
\text { Kimble, 1999) }\end{array}$ & $92 \% \mathrm{~B}$ \\
\hline$m o g-4$ & $\begin{array}{l}\text { global repressor of } \mathrm{fem}-3 \text { translation } \\
\text { (female-promoting) }\end{array}$ & $\begin{array}{l}\text { DEAH RNA helicase (Puoti and } \\
\text { Kimble, 2000) }\end{array}$ & $90 \% \mathrm{~B}$ \\
\hline $\operatorname{mog}-5$ & $\begin{array}{l}\text { global repressor of } \mathrm{fem}-3 \text { translation } \\
\text { (female-promoting) }\end{array}$ & $\begin{array}{l}\text { DEAH RNA helicase (Puoti and } \\
\text { Kimble, 2000) }\end{array}$ & $92 \% \mathrm{~B}$ \\
\hline $\begin{array}{l}\text { mog-6 (aka } \\
\text { cyp-4) }\end{array}$ & $\begin{array}{l}\text { global repressor of } \mathrm{fem}-3 \text { translation } \\
\text { (female-promoting) }\end{array}$ & $\begin{array}{l}\text { divergent cyclophilin (Belfiore et } \\
\text { al., 2004) }\end{array}$ & $92 \% \mathrm{~B}$ \\
\hline tra-1 & $\begin{array}{l}\text { global regulator of sex-specific } \\
\text { transcription (female-promoting) }\end{array}$ & $\begin{array}{l}\text { Zn-finger TF (Zarkower and } \\
\text { Hodgkin, 1992) }\end{array}$ & $\begin{array}{l}\text { 44\% (de Bono and } \\
\text { Hodgkin, 1996) }\end{array}$ \\
\hline fog-1 & $\begin{array}{l}\text { promoter of spermatogenesis } \\
\text { (male-promoting) }\end{array}$ & $\begin{array}{l}\text { CPEB (Jin et al., 2001; Luitjens et } \\
\text { al., 2000) }\end{array}$ & $60 \% \mathrm{G}$ \\
\hline fog-3 & $\begin{array}{l}\text { promoter of spermatogenesis } \\
\text { (male-promoting) }\end{array}$ & TOB family (Chen et al., 2000) & $\begin{array}{l}56 \% \text { (Chen et al., } \\
2001 \text { ) }\end{array}$ \\
\hline$m a b-3$ & $\begin{array}{l}\text { regulator of male tail and neuron } \\
\text { development (male-promoting) }\end{array}$ & DM domain (Raymond et al., 1998) & $67 \% \mathrm{G}$ \\
\hline \multicolumn{4}{|c|}{$\begin{array}{l}\text { Genes are arranged by where they act in the pathway, with sex chromosome counting elements at the top and } \\
\text { tissue-specific targets of TRA-1 at the bottom. Percent identities are based on published figures when available, on } \\
\text { BLAST } 2.0 \text { alignments of predicted genes from WormBase when alignable over at least } 90 \% \text { of their full length } \\
\text { (B), or on whole alignments using the Needleman \& Wunsch algorithm as implemented in the Gap program of the } \\
\text { GCG Wisconsin Package (G). Genes that have not yet been cloned, or whose products are involved in dosage } \\
\text { compensation but not sex determination, are omitted here for simplicity. The median amino acid identity across the } \\
\text { entire set of C. elegans-C. briggsae orthologs is } 80 \% \text { (Stein and others, 2003). P, based on partial sequence; TF, } \\
\text { transcription factor; RRM, RNA recognition motif. }\end{array}$} \\
\hline
\end{tabular}

Even well-conserved proteins can rapidly change their role (or lack thereof) in sex determination, as has been found in dipteran insects (reviewed by Graham et al., 2003). Evidence for similar change in nematodes is discussed below. In contrast, some proteins exhibiting rapid sequence change participate in conserved protein-protein interactions with a consistent role in sex determination. For example, the TRA-1/TRA-2c interaction is conserved in C. briggsae, and this interaction is species-specific (Wang and Kimble, 2001). A more extreme case of molecular coevolution exists between TRA-2c and FEM-3. The FEM-3 binding domain of TRA-2c is conspicuously hyperdivergent (Haag and Kimble, 2000; Kuwabara, 1996), yet mediates a strong but species-specific interaction with the similarly divergent FEM-3 in C. elegans, C. briggsae, and C. remanei (Haag et al., 2002). Why and how crucial protein-protein interactions mediating sex determination are continually reinvented at the primary sequence level are interesting questions that will require the integration of structural biology, genetics, and ecology to be fully answered. 


\section{Two cases of species-specific genes}

Though most $C$. elegans sex determination genes have a single $C$. briggsae ortholog, there are two exceptions. fog-2 is clearly the result of a recent, elegans-specific tandem duplication (Clifford et al., 2000). FOG-2 differs little from the protein encoded by its nearest neighbor and most similar paralog, FTR-1, over its N-terminal $80 \%$, but has a distinct C-terminus. This divergent region is necessary and sufficient for GLD-1 binding, and may be derived from the ancestral domain in part via a frame-shift mutation (Nayak et al., 2005). fog-2 likely reveals the footprints of a key event in the evolution of hermaphroditism in the C. elegans lineage. This will be discussed at greater length below.

The second example of species-specific sex determination genes is that of $f b f-1$ and $f b f-2$. These two Puf family genes are also the product of a recent tandem duplication, and encode proteins that are $91 \%$ identical (Zhang et al., 1997). Three $C$. briggsae genes, themselves products of recent lineage-specific duplication events, are more closely related to the $f b f s$ than to any other $C$. briggsae family members (Lamont et al., 2004, A. Doty, unpublished data). However, the expectation that any of these three $C$. briggsae genes perform the function of $f b f$ in repressing fem-3 is complicated by the lack of $C b-f e m-3(R N A i)$ germline feminization (Haag et al., 2002). It may be that these $f b f$-related $C$. briggsae Puf proteins regulate $C b$-fem-3, but only in the soma, or have other targets entirely.

\section{Comparative functional studies}

Several labs have investigated the function of homologs of C. elegans sex determination genes. An early study on C. briggsae tra-1 (de Bono and Hodgkin, 1996) employed partial rescue of C. elegans mutants to demonstrate conservation of function. However, the discovery of RNAi has had a profound impact. Kuwabara (1996) first showed the efficacy of RNAi in a non-elegans species, against $\mathrm{Cb}$-tra-2. Although rescue assays have continued to be used (Chen et al., 2001; Hansen and Pilgrim, 1998), the phenomenon of interspecies protein-protein incompatibility discussed above makes partial or failed interspecies rescue uninformative. Unfortunately, RNAi has its own problems, the chief being its frequently lower effectiveness in C. briggsae and C. remanei than in C. elegans (Haag and Kimble, 2000; Haag et al., 2002; Kuwabara, 1996, M. Montgomery, pers. comm.). For this reason, several laboratories have begun forward and reverse genetic screens for true sex determination mutations in $C$. briggsae (D. Pilgrim, E. Haag, and R. Ellis, unpublished data). In Pristionchus pacificus, both morpholino oligonucleotides and forward mutagenesis screens have recently been employed with success (Pires-daSilva and Sommer, 2004).

Despite these technical difficulties, sex determination function has already been demonstrated for numerous orthologs of key $C$. elegans genes. $C b$-her- 1 is required for normal male development, and its overexpression clearly masculinizes XX C. elegans animals. Overexpression of her-1 from the filarial parasite Brugia malayi was less successful (Streit et al., 1999). tra-2 has conserved roles in both the soma and germ line of $C$. briggsae (Kuwabara, 1996) and $C$. remanei (Haag and Kimble, 2000), and in vitro and in vivo evidence exists for its translational repression in these species (Haag and Kimble, 2000; Jan et al., 1997). Similarly, tra-1 performs a key female-promoting role in other species, both across Caenorhabditis (de Bono and Hodgkin, 1996) and in the neodiplogasterid Pristionchus pacificus (Pires-daSilva and Sommer, 2004).

The fem genes of non-elegans Caenorhabditis species have also been studied, with more surprising results. Although fem-1, fem-2, and fem-3 perform conserved roles in somatic sex determination, RNAi data (Haag et al., 2002; Stothard et al., 2002) and two mutations (Hill et al., unpublished data) indicate that they are dispensable for hermaphrodite spermatogenesis in C. briggsae. In addition, fem-1 (A. Spence, pers. comm.) and fem-3 (Haag et al., 2002) are probably not required for at least some male spermatogenesis. Despite these differences, however, the germline-specific fog- 1 and fog-3 have conserved roles in promoting spermatogenesis (Chen et al., 2001). The potential significance of these results is discussed further below.

\section{Mating system evolution in Caenorhabditis}

From a phylogenetic perspective, $C$. elegans is rather unusual in having a hermaphrodite sex. Its combination with males, termed androdioecy, is found in animals only in other nematodes and some crustaceans (Sassaman, 1995; Sassaman and Weeks, 1993). With the exception of C. briggsae, the remaining Caenorhabditis species are all gonochoristic (male/female). That hermaphroditic Caenorhabditis are derived from gonochoristic ancestors has been accepted for many years (Honda, 1925), as has the independent origin of selfing in distantly related species (Fitch, 2002). However, recent phylogenies suggest that even $C$. elegans and $C$. briggsae acquired their shared 
hermaphroditism via parallel evolution (Cho et al., 2004; Kiontke et al., 2004). An independent origin of bisexual germline development may help explain discrepancies in germline gene function that have begun to emerge from comparative functional studies.

In $C$. elegans, the core somatic pathway is also required for normal germline sex determination, although its regulation differs from the soma in some details (Figure 3A). First, a direct TRA-1/TRA-2c interaction (Lum et al., 2000; Wang and Kimble, 2001) is required for reliable hermaphrodite spermatogenesis. Lum et al. (2000) suggested that this interaction, while generally female-promoting, is a necessary prerequisite for full repression of tra-2 that allows initiation of hermaphrodite spermatogenesis. Second, the fem genes positively regulate spermatogenesis (Hodgkin, 1986) and germline-specific fog-3 transcription (Chen and Ellis, 2000) in the absence of tra-1. Finally, tra-1 loss-of-function mutants cannot sustain spermatogenesis, a phenotype at odds with their complete somatic masculinization (Schedl et al., 1989). This long-puzzling result may stem from both positive and negative regulation of fog-3 by TRA-1 (Chen and Ellis, 2000).

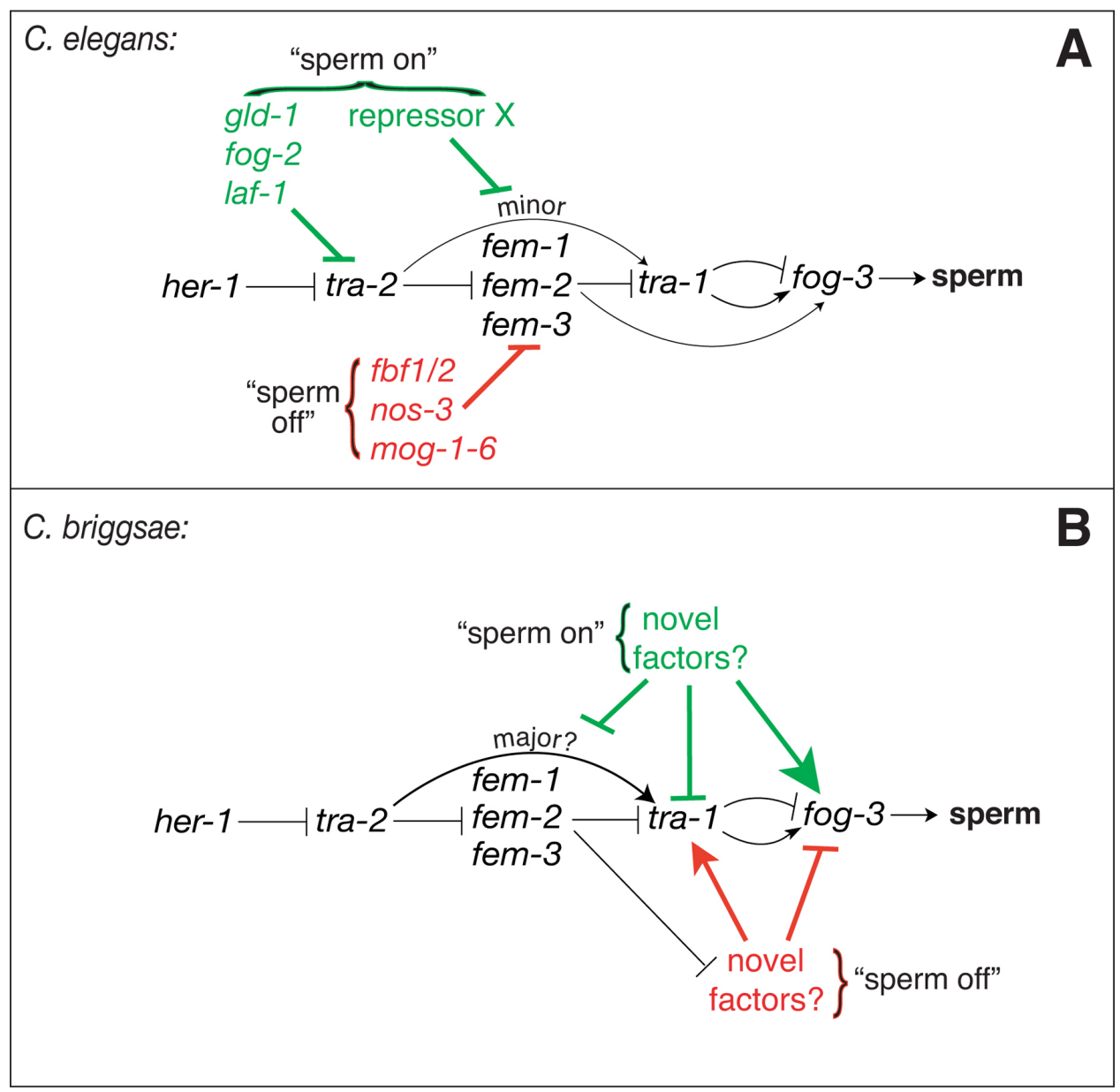

Figure 3. Models for germline sex determination in C. elegans and C. briggsae. (A) C. elegans, and (B) C. briggsae. In both panels, arrows indicate positive regulation, and crossbars indicate repressive regulation. With the exception of fog-3, the genes in black type are also crucial in somatic sex determination. Mechanisms promoting the initiation of hermaphrodite spermatogenesis are colored green, and those promoting the switch to oogenesis are colored red. Though it is likely that $C$. briggsae hermaphroditism is controlled by genes regulating the core pathway downstream of the $C b$-fems, their identity is unknown. See text for full explanation.

Numerous studies have investigated the germline-specific regulation that enables hermaphrodite germ cells to change sex during development (Figure 3A). Translational repression of tra-2 by the GLD-1/FOG-2 complex (Clifford et al., 2000; Goodwin et al., 1993; Jan et al., 1999) is thought to be the major factor allowing hermaphrodite spermatogenesis to start ("sperm on"). The switch to oogenesis depends crucially upon translational repression of fem-3 by the FBF/NOS-3 complex (Ahringer and Kimble, 1991; Ahringer et al., 1992; Gallegos et al., 1998; Kraemer et al., 1999; Zhang et al., 1997). 
How much of the regulation described above is used by $C$. briggsae hermaphrodites? There is evidence that the repression of tra-2 by a GLD-1-like factor (Jan et al., 1999) and a TRA-1/TRA-2c direct interaction (Wang and Kimble, 2001) both occur. This is consistent with a central role for tra-2 regulation in the initiation of $C$. briggsae hermaphrodite spermatogenesis (Figure 3B). However, fog-2, a key cofactor of GLD-1, is unique to C. elegans (see above). In addition, RNAi directed against the $C$. briggsae gld-1 ortholog causes highly penetrant germline masculinization, not the feminization expected from $C$. elegans (Nayak et al., 2005). As discussed by Nayak et al. (2005), these latter results suggest several alternative possibilities. One is that $C b$-GLD-1 does not translationally repress $C b$-tra-2, or that it does but also has other, male-promoting targets that are more important. Alternatively, fog- 2 may qualitatively modify the function of $C e$-GLD-1 in a conserved GLD-1/tra-2 interaction. It is still possible, however, that the unexpected $C b$-gld-1(RNAi) phenotype is due to incomplete inactivation of $C b-g l d-1$, as RNAi is generally less effective in C. briggsae (Haag et al., 2002, M. Montgomery, pers. comm.). Mutations in $C b$-gld- 1 will be required to clarify this matter.

In addition to the evolution of the "sperm on" portion of hermaphrodite germline development, evidence is mounting that the "sperm off" component is also distinct. While the Cb-fem genes have conserved roles in male somatic development, none have yet been shown to be required for hermaphrodite spermatogenesis (Haag et al., 2002, A. Spence, pers. comm.; Stothard et al., 2002, Hill et al., unpublished data). Thus the "sperm off" function must target other parts of the pathway, suggested here (Figure 3B) to be variously the TRA-1/TRA-2c interaction, direct upregulation of tra-1, or repression of fog-3. fog-3 expression is tightly associated with sperm production in both species, as well as in $C$. remanei (Chen et al., 2001). Surprisingly, $C b$-fem-2 and $C b$-fem-3 null XO mutants are neither females (Fog), as would be the case in C. elegans, nor somatic females with spermatogenic germ lines (Mog), as might be expected from the lack of phenotype in XX hermaphrodites. Instead, these XO mutants are also hermaphrodites (the Her phenotype; Hill et al., unpublished data). This suggests that the $\mathrm{Cb}$-fem genes are neither required to initiate nor to curtail hermaphrodite spermatogenesis, but do act to repress the sperm-oocyte switch in $\mathrm{XO}$ males. Overall, it is likely the entire control of hermaphrodite spermatogenesis lies downstream of the fem genes in C. briggsae (Figure 3B).

The question of how hermaphrodites differ from their female ancestors has motivated much of the comparative work on Caenorhabditis sex determination. C. briggsae and C. remanei represent the most closely related gonochoristic/androdioecious species pair (Cho et al., 2004; Kiontke et al., 2004), and thus make an especially informative comparative system for future research. More distantly related hermaphrodite species exist that have convergently evolved selfing (Fitch, 2002). The availability of both closely related species with different mating systems and multiple cases of parallel evolution of a complex trait makes soil nematodes an attractive system for developmental studies of reproductive adaptation. Rapid developments in genome sequencing and the advent of comparative genetics are making rigorous studies in these other species possible, and not only for sex determination. However, given the intrinsic organismal importance and remarkably rapid evolution of sex determination, it is likely that it will remain a major topic in nematode comparative biology for the foreseeable future.

\section{Acknowledgements}

The author thanks Dave Pilgrim, Elizabeth Goodwin, Tim Schedl, Ron Ellis, Judith Kimble, and Andrew Spence for sharing results prior to publication, and Barbara Meyer and two anonymous reviewers for helpful comments on an early draft of this manuscript. Research in the Haag Lab is supported by the National Science Foundation.

\section{References}

Ahringer, J., and Kimble, J. (1991). Control of the sperm-oocyte switch in Caenorhabditis elegans hermaphrodites by the fem-3 3' untranslated region. Nature 349, 346-348. Abstract Article

Ahringer, J., Rosenquist, T., Lawson, D., and Kimble, J. (1992). The Caenorhabditis elegans sex determining gene fem-3 is regulated post-transcriptionally. EMBO J. 11, 2303-2310. Abstract

Anderson, R. (2000). Nematode parasites of vertebrates, 2nd edn. (Wallingford, UK, CABI Publishing).

Ashton, F.T., Bhopale, V.M., Holt, D., Smith, G., and Schad, G.A. (1998). Developmental switching in the parasitic nematode Strongyloides stercoralis is controlled by the ASF and ASI amphidial neurons. J. Parasitol. 84, 691-695. Abstract 
Barnes, T.M., and Hodgkin, J. (1996). The tra-3 sex determination gene of Caenorhabditis elegans encodes a member of the calpain regulatory protease family. EMBO J. 15, 4477-4484. Abstract Article

Belfiore, M., Pugnale, P., Saudan, Z., and Puoti, A. (2004). Roles of the C. elegans cyclophilin-like protein MOG-6 in MEP-1 binding and germline fates. Development 131, 2935-2945. Abstract Article

Bull, J. (1981). Evolution of environmental sex determination from genotypic sex determination. Heredity 47, $173-184$.

Bull, J. (1983). Evolution of sex determining mechanisms, Vol. 1 (Menlo Park, CA: Benjamin Cummings Publishing Co.).

Carmi, I., Kopczynski, J.B., and Meyer, B.J. (1998). The nuclear hormone receptor SEX-1 is an X-chromosome signal that determines nematode sex. Nature 396, 168-173. Abstract Article

Chan, R.C., Severson, A.F., and Meyer, B.J. (2004). Condensin restructures chromosomes in preparation for meiotic divisions. J. Cell Biol. 167, 613-625. Abstract Article

Chen, P., Cho, S., Jin, S., and Ellis, R. (2001). Specification of germ cell fates by FOG-3 has been conserved during nematode evolution. Genetics 158, 1513-1525. Abstract

Chen, P., and Ellis, R.E. (2000). tra-1A regulates transcription of fog-3, which controls germ cell fate in C. elegans. Development 127, 3119-3129. Abstract

Chen, P., Singal, A., Kimble, J., and Ellis, R. (2000). A novel member of the tob family of proteins controls sexual fate in Caenorhabditis elegans germ cells. Dev. Biol. 217, 77-90. Abstract Article

Chitwood, B., and Chitwood, M. (1950). Introduction to Nematology (Baltimore: University Park Press).

Cho, S., Jin, S.W., Cohen, A., and Ellis, R.E. (2004). A phylogeny of caenorhabditis reveals frequent loss of introns during nematode evolution. Genome Res. 14, 1207-1220. Abstract Article

Christie, J. (1929). Some observations on sex in the Mermithidae. J. Exp. Zool. 53, 59-76. Article

Clifford, R., Lee, M., Nayak, S., Ohmachi, M., Giorgini, F., and Schedl, T. (2000). FOG-2, a novel F-box-containing protein, associates with the GLD-1 RNA-binding protein and directs male sex determination in the C. elegans hermaphrodite germline. Development 127, 5265-5276. Abstract

Cline, T., and Meyer, B. (1996). Vive la difference: males vs. females in flies vs. worms. Annu. Rev. Genet. 30, 637-702. Abstract Article

Crittenden, S.L., Bernstein, D.S., Bachorik, J.L., Thompson, B.E., Gallegos, M., Petcherski, A.G., Moulder, G., Barstead, R., Wickens, M., and Kimble, J. (2002). A conserved RNA-binding protein controls germline stem cells in Caenorhabditis elegans. Nature 417, 660-663. Abstract Article

Dawes, H.E., Berlin, D.S., Lapidus, D.M., Nusbaum, C., Davis, T.L., and Meyer, B.J. (1999). Dosage compensation proteins targeted to X chromosomes by a determinant of hermaphrodite fate. Science 284, 1800-1804. Abstract Article

de Bono, M., and Hodgkin, J. (1996). Evolution of sex determination in Caenorhabditis: unusually high divergence of tra- 1 and its functional consequences. Genetics 144, 587-595. Abstract

Fitch, D., ed. (2002). Ch. 2 of Appendix, Phylogeny, of WormAtlas (http://www.wormatlas.org) (WormAtlas Consortium).

Francis, R., Barton, M.K., Kimble, J., and Schedl, T. (1995). gld-1, a tumor suppressor gene required for oocyte development in Caenorhabditis elegans. Genetics 139, 579-606. Abstract 
Gallegos, M., Ahringer, J., Crittenden, S., and Kimble, J. (1998). Repression by the 3'UTR of fem-3, a sex-determining gene, relies on a ubiquitous mog -dependent control in Caenorhabditis elegans. EMBO J. 17, 6337-6347. Abstract Article

Goodwin, E.B., Okkema, P.G., Evans, T.C., and Kimble, J. (1993). Translational regulation of tra-2 by its 3' untranslated region controls sexual identity in C. elegans. Cell 75, 329-339. Abstract Article

Graham, P., Penn, J.K., and Schedl, P. (2003). Masters change, slaves remain. BioEssays 25, 1-4. Abstract Article

Haag, E., and Kimble, J. (2000). Regulatory elements required for development of C. elegans hermaphrodites are conserved in the tra-2 homologue of $C$. remanei, a male/female sister species. Genetics $155,105-116$. Abstract

Haag, E., Wang, S., and Kimble, J. (2002). Rapid coevolution of the nematode sex-determining genes fem-3 and tra-2. Curr. Biol. 12, 2035-2041. Abstract Article

Hagstrom, K.A., Holmes, V.F., Cozzarelli, N.R., and Meyer, B.J. (2002). C. elegans condensin promotes mitotic chromosome architecture, centromere organization, and sister chromatid segregation during mitosis and meiosis. Genes Dev. 16, 729-742. Abstract Article

Hamaoka, B.Y., Dann, C.E., III, Geisbrecht, B.V., and Leahy, D.J. (2004). Crystal structure of Caenorhabditis elegans her-1 and characterization of the interaction between her-1 and TRA-2A. Proc. Natl. Acad. Sci. USA 101, 11673-11678. Abstract Article

Hansen, D., Hubbard, E.J., and Schedl, T. (2004). Multi-pathway control of the proliferation versus meiotic development decision in the Caenorhabditis elegans germline. Dev. Biol. 268, 342-357. Abstract Article

Hansen, D., and Pilgrim, D. (1998). Molecular evolution of a sex determination protein. FEM-2 (pp2c) in Caenorhabditis. Genetics 149, 1353-1362. Abstract

Harlos, J., Brust, R., and Galloway, T. (1980). Observations on a nematode parasite of Aedes vexans (Diptera: Culicidae) in Manitoba. Can. J. Zool. 58, 215-220.

Hodgkin, J. (1986). Sex determination in the nematode Caenorhabditis elegans: analysis of tra-3 suppressors and characterization of fem genes. Genetics 114, 15-52. Abstract

Hodgkin, J. (2002). Exploring the envelope. Systematic alteration in the sex-determination system of the nematode Caenorhabditis elegans. Genetics 162, 767-780. Abstract

Hodgkin, J., and Brenner, S. (1977). Mutations causing transformation of sexual phenotype in the nematode Caenorhabditis elegans. Genetics 86, 275-287. Abstract

Hodgkin, J., Zellan, J.D., and Albertson, D.G. (1994). Identification of a candidate primary sex determination locus, fox-1, on the X chromosome of Caenorhabditis elegans. Development 120, 3681-3689. Abstract

Honda, H. (1925). Experimental and cytological studies on bisexual and hermaphrodite free living nematodes, with special reference to problems of sex. J. Morph. Physiol. 40, 191-233. Article

Jan, E., Motzny, C.K., Graves, L.E., and Goodwin, E.B. (1999). The STAR protein, GLD-1, is a translational regulator of sexual identity in Caenorhabditis elegans. EMBO J. 18, 258-269. Abstract Article

Jan, E., Yoon, J.W., Walterhouse, D., Iannaccone, P., and Goodwin, E.B. (1997). Conservation of the C. elegans tra-2 3' UTR translational control. EMBO J. 16, 6301-6313. Abstract Article

Jin, S.W., Kimble, J., and Ellis, R.E. (2001). Regulation of cell fate in Caenorhabditis elegans by a novel cytoplasmic polyadenylation element binding protein. Dev. Biol. 229, 537-553. Abstract Article

Jones, A.R., Francis, R., and Schedl, T. (1996). GLD-1, a cytoplasmic protein essential for oocyte differentiation, shows stage- and sex-specific expression during Caenorhabditis elegans germline development. Dev. Biol. 180, 165-183. Abstract Article 
Jones, A.R., and Schedl, T. (1995a). Mutations in gld-1, a femal germ cell-specific tumor suppressor gene in Caenorhabditis elegans, affect a conserved domain also found in Src-associated protein Sam68. Genes Dev. 9, 1491-1504. Abstract

Kadyk, L.C., and Kimble, J. (1998). Genetic regulation of entry into meiosis in Caenorhabditis elegans. Development 125, 1803-1813. Abstract

Kiontke, K., Gavin, N.P., Raynes, Y., Roehrig, C., Piano, F., and Fitch, D.H. (2004). Caenorhabditis phylogeny predicts convergence of hermaphroditism and extensive intron loss. Proc. Natl. Acad. Sci. USA 101, 9003-9008. Abstract Article

Klein, R.D., and Meyer, B.J. (1993). Independent domains of the Sdc-3 protein control sex determination and dosage compensation in C. elegans. Cell 72, 349-364. Abstract Article

Kraemer, B., Crittenden, S., Gallegos, M., Moulder, G., Barstead, R., Kimble, J., and Wickens, M. (1999). NANOS-3 and FBF proteins physically interact to control the sperm-oocyte switch in Caenorhabditis elegans. Curr. Biol. 9, 1009-1018. Abstract Article

Kuwabara, P.E. (1996). Interspecies comparison reveals evolution of control regions in the nematode sex-determining gene tra-2. Genetics 144, 597-607. Abstract

Kuwabara, P.E., and Kimble, J. (1995). A predicted membrane protein, TRA-2A, directs hermaphrodite development in Caenorhabditis elegans. Development 121, 2995-3004. Abstract

Lamont, L.B., Crittenden, S.L., Bernstein, D., Wickens, M., and Kimble, J. (2004). FBF-1 and FBF-2 regulate the size of the mitotic region in the C. elegans germline. Dev. Cell 7, 697-707. Abstract Article

Li, W., Boswell, R., and Wood, W. (2000). mag-1, a homolog of Drosophila mago nashi, regulates hermaphrodite germ-line sex determination in Caenorhabditis. Dev. Biol. 218, 172-182. Abstract Article

Luitjens, C., Gallegos, M., Kraemer, B., Kimble, J., and Wickens, M. (2000). CPEB proteins control two key steps in spermatogenesis in C. elegans. Genes Dev. 14, 2596-2609. Abstract Article

Lum, D., Kuwabara, P., Zarkower, D., and Spence, A. (2000). Direct protein-protein interaction between the intracellular domain of TRA-2 and the transcription factor tra-1A modulates feminizing activity in C. elegans. Genes Dev. 14, 3153-3165. Abstract

Luz, J.G., Hassig, C.A., Pickle, C., Godzik, A., Meyer, B.J., and Wilson, I.A. (2003). XOL-1, primary determinant of sexual fate in C. elegans, is a GHMP kinase family member and a structural prototype for a class of developmental regulators. Genes Dev. 17, 977-990. Abstract Article

Madl, J.E., and Herman, R.K. (1979). Polyploids and sex determination in Caenorhabditis elegans. Genetics 93, 393-402. Abstract

Matsuda, M., Nagahama, Y., Shinomiya, A., Sato, T., Matsuda, C., Kobayashi, T., Morrey, C.E., Shibata, N., Asakawa, S., Shimizu, N., et al. (2002). DMY is a Y-specific DM-domain gene required for male development in the medaka fish. Nature 417, 559-563. Abstract Article

Meyer, B.J. (2000). Sex in the worm: counting and compensating X-chromosome dose. Trends Genet. 16, 247-253. Abstract Article

Miller, S.W., Hayward, D.C., Bunch, T.A., Miller, D.J., Ball, E.E., Bardwell, V.J., Zarkower, D., and Brower, D.L. (2003). A DM domain protein from a coral, Acropora millepora, homologous to proteins important for sex determination. Evol. Dev. 5, 251-258. Abstract Article

Nayak, S., Goree, J., and Schedl, T. (2005). fog-2 and the evolution of self-fertile hermaphroditism in Caenorhabditis. PLoS Biology 3, e6. Abstract Article 
Nigon, V. (1949). Les modalites de la reproduction et le determinisme de sexe chez quelques Nematodes libres. Ann. Sci. Nat. Zool. ser. 11, 2, 1-132.

Nonet, M.L., and Meyer, B.J. (1991). Early aspects of Caenorhabditis elegans sex determination and dosage compensation are regulated by a zinc-finger protein. Nature 351, 65-68. Abstract Article

Perry, M.D., Li, W., Trent, C., Robertson, B., Fire, A., Hageman, J.M., and Wood, W.B. (1993). Molecular characterization of the her-1 gene suggests a direct role in cell signaling during Caenorhabditis elegans sex determination. Genes Dev. 7, 216-228. Abstract

Petersen, J.J. (1985). Nematodes as biological control agents: Part I. Mermithidae. Adv. Parasitol. 24, $307-344$. Abstract

Pilgrim, D., McGregor, A., Jackle, P., Johnson, T., and Hansen, D. (1995). The C. elegans sex-determining gene fem-2 encodes a putative protein phosphatase. Mol. Biol. Cell 6, 1159-1171. Abstract

Pires-daSilva, A., and Sommer, R.J. (2004). Conservation of the global sex determination gene tra-1 in distantly related nematodes. Genes Dev. 18, 1198-1208. Abstract Article

Poinar, G., Jr. (2002). First fossil record of nematode parasitism of ants; a 40 million year tale. Parasitology 125 , 457-459. Abstract Article

Prahlad, V., Pilgrim, D., and Goodwin, E.B. (2003). Roles for mating and environment in C. elegans sex determination. Science 302, 1046-1049. Abstract Article

Puoti, A., and Kimble, J. (1999). The Caenorhabditis elegans sex determination gene mog-1 encodes a member of the DEAH-box protein family. Mol. Cell Biol. 19, 2189-2197. Abstract

Puoti, A., and Kimble, J. (2000). The hermaphrodite sperm/oocyte switch requires the Caenorhabditis elegans homologs of PRP2 and PRP22. Proc. Natl. Acad. Sci. USA 97, 3276-3281. Abstract Article

Raymond, C., Shamu, C., Shen, M., Seifert, K., Hirsch, B., Hodgkin, J., and Zarkower, D. (1998). Evidence for evolutionary conservation of sex-determining genes. Nature 391, 873-881. Abstract Article

Sassaman, C. (1995). Sex determination and evolution of unisexuality in the Conchostraca. Hydrobiologia 298, 45-65. Article

Sassaman, C., and Weeks, S.C. (1993). The genetic mechanism of sex determination in the conchostracan shrimp Eulimnadia texana. Am. Nat. 141, 314-328. Article

Schedl, T., Graham, P.L., Barton, M.K., and Kimble, J. (1989). Analysis of the role of tra-1 in germline sex determination in the nematode Caneorhabditis elegans. Genetics 123, 755-769. Abstract

Spence, A., Coulson, A., and Hodgkin, J. (1990). The product of fem-1, a nematode sex-determining gene, contains a motif found in cell cycle control proteins and receptors for cell-cell interactions. Cell 60, 981-990. Abstract Article

Stein, L., and others (2003). The genome sequence of Caenorhabditis briggsae: a platform for comparative genomics. PLoS Biology 1, 166-192. Abstract Article

Stothard, P., Hansen, D., and Pilgrim, D. (2002). Evolution of the PP2C family in Caenorhabditis: rapid divergence of the sex-determining protein FEM-2. J. Mol. Evol. 54, 267-282. Abstract Article

Streit, A., Li, W., Robertson, B., Schein, J., Kamal, I., Marra, M., and Wood, W. (1999). Homologs of the Caenorhabditis elegans masculinizing gene her-1 in C. briggsae and the filarial parasite Brugia malayi. Genetics 152, 1573-1584. Abstract

Wang, S., and Kimble, J. (2001). The tra-1 transcription factor binds TRA-2 to regulate sexual fates in Caenorhabditis elegans. EMBO J. 20, 1363-1372. Abstract Article 
Wilkins, A. (1995). Moving up the hierarchy: a hypothesis on the evolution of a genetic sex determination pathway. BioEssays 17, 71-77. Abstract Article

Yi, W., and Zarkower, D. (1999). Similarity of DNA binding and transcriptional regulation by Caenorhabditis elegans MAB-3 and Drosophila melanogaster DSX suggests conservation of sex determining mechanisms. Development 126, 873-881. Abstract

Zarkower, D., and Hodgkin, J. (1992). Molecular analysis of the C. elegans sex-determining gene tra-1: a gene encoding two zinc finger proteins. Cell 70, 237-249. Abstract Article

Zhang, B., Gallegos, M., Puoti, A., Durkin, A., Fields, S., Kimble, J., and Wickens, M.P. (1997). A conserved RNA binding protein that regulates sexual fates in the C. elegans hermaphrodite germ line. Nature 390, 477-484. Abstract Article

All WormBook content, except where otherwise noted, is licensed under a Creative Commons Attribution License. 